\section{PEPPERDINE \\ UNIVERSITY}

Journal of the National Association of

Administrative Law Judiciary

$12-15-2016$

\title{
The Rowley Enigma: How Much Weight is Due to IDEA State Administrative Proceedings in Federal Court?
}

Daniel W. Morton-Bentley

Follow this and additional works at: https://digitalcommons.pepperdine.edu/naalj

Part of the Administrative Law Commons, Disability Law Commons, and the Education Law Commons

\section{Recommended Citation}

Daniel W. Morton-Bentley, The Rowley Enigma: How Much Weight is Due to IDEA State Administrative Proceedings in Federal Court?, 36 J. Nat'l Ass'n Admin. L. Judiciary 428 (2016)

Available at: https://digitalcommons.pepperdine.edu/naalj/vol36/iss2/2

This Article is brought to you for free and open access by the Caruso School of Law at Pepperdine Digital Commons. It has been accepted for inclusion in Journal of the National Association of Administrative Law Judiciary by an authorized editor of Pepperdine Digital Commons. For more information, please contact bailey.berry@pepperdine.edu. 


\section{The Rowley Enigma: How Much Weight is Due to IDEA State Administrative Proceedings in Federal Court?}

\section{By Daniel W. Morton-Bentley*}

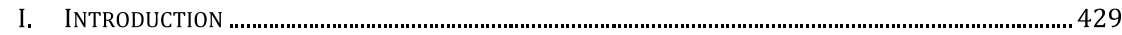

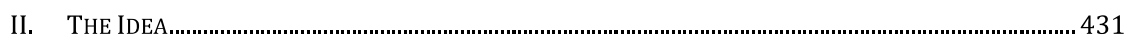

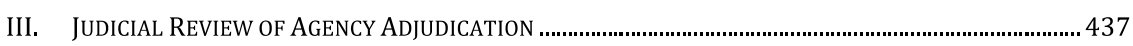

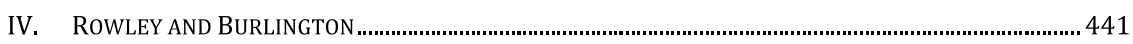

A. Board of Education of the Hendrick Hudson Central

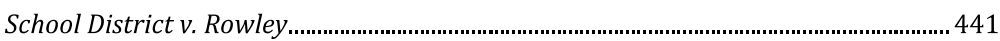

B. Town of Burlington v. Department of Education for the

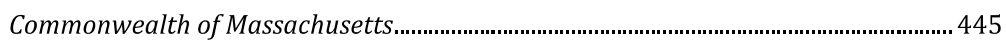

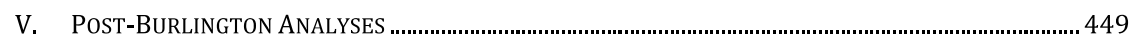

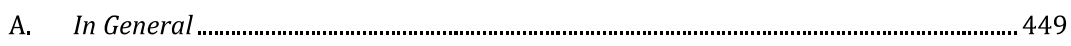

B. The Majority Approach: Infinite Discretion …………………………………….............. 452

C. The Minority Approach: Deference for Educational Findings ....................................... 458

VI. PRoCEDURE VERSUS SUBSTANCE: A REASONED APPROACH TO DEFERENCE ..........................................462

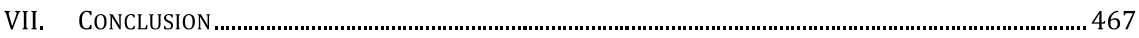




\section{INTRODUCTION}

The Individuals with Disabilities Education Act (IDEA) allows parents of students with disabilities to seek review of educational decisions made by school districts. ${ }^{1}$ The process begins with a state administrative hearing where the parties present evidence before a hearing officer. ${ }^{2}$ Depending on the state, the parties may be required to undergo a second level of state administrative review. ${ }^{3}$ The final administrative decision may then be appealed to a state or federal court. ${ }^{4}$ In Board of Education of the Hendrick Hudson Central School Dist. v. Rowley, the U.S. Supreme Court held that courts must give "due weight" to these state administrative proceedings. ${ }^{5}$ The Court based its conclusion on the IDEA's system of cooperative federalism as well as the notion that state educational authorities are better equipped than federal judges to assess issues of educational policy.

In the ensuing years, the majority of federal courts ${ }^{6}$ have drifted away from Rowley's holding by defining "due weight" in a way that allows them to ignore the findings of the state administrative

* Assistant Counsel, New York State Education Department; LL.M, Suffolk University Law School; J.D., Roger Williams University School of Law. Many thanks to Kyla Houge and the editorial staff of the Journal of the National Association of Administrative Law Judiciary for their thorough editorial review. Thanks also to Professor Gregory Ogden and, as always, Kaitlin Morton-Bentley. The views expressed in this article are the author's own.

${ }^{1} 20$ U.S.C. $\S 1400$ (2012).

${ }^{2}$ See infra Part II and accompanying notes.

${ }^{3}$ See infra Part II and accompanying notes.

${ }^{4}$ See infra Part II and accompanying notes.

${ }^{5} 458$ U.S. 176, 206 (1982).

6 This article focuses on the federal judiciary, as federal review of state administrative proceedings present federalism concerns not present in state courts. Nevertheless, because the IDEA's judicial review provision does not distinguish between state and federal review, the below discussion is otherwise germane to state appeals, unless state law specifies a different standard of review. See, e.g., Pawling Cent. Sch. Dist. v. N.Y. State Educ. Dep't, 771 N.Y.S.2d 572, 576, n.3 (2004) (noting that the state legislature passed bill altering the standard of review for IDEA appeals filed in state court); Town of Burlington v. Dep't of Educ. of Com. of Mass., 655 F.2d 428, 431-32 (1st Cir. 1981) (observing that differing standards of IDEA review in state and federal court "present[s] the specter of inconsistent federal and state judgments ...."). 
proceedings. ${ }^{7}$ In this article, I argue that the phrase "due weight" incorporates a deferential review standard equivalent to the clear error or substantial evidence standard, a conclusion reached by a minority of the circuit courts of appeal. ${ }^{8}$ I further argue that, consistent with Rowley, federal courts must afford due weight to administrative officers' substantive or educational conclusions, but no weight to their procedural or non-educational conclusions.

While the language of deference can be dry, its substance is anything but. Deference is about who gets the power to make important decisions. It can determine whether a school district or a family pays private tuition costs, or whether a school district is responsible for attorneys' fees. Either of these costs can reach hundreds of thousands of dollars. ${ }^{9}$ It also, more importantly, affects the stability of the education of a student with a disability, which rests upon the final determination of an agency or court.

Part II offers a general outline of the IDEA, giving special attention to its judicial review provisions. In Part III, I provide a general discussion of judicial review of administrative adjudication. Part IV is devoted to a discussion of Rowley and the First Circuit's

7 Throughout this article, "deference" and "standard of review" are used interchangeably. A standard of review is "[t]he criterion by which an appellate court exercising appellate jurisdiction measures the . . . propriety of an order, finding, or judgment entered by a lower court" or administrative tribunal. Standard of Review, Black's Law Dictionary (10th ed. 2014). Deference, in its intransitive verb form, means "to submit to another's wishes, opinion, or governance usually through deference or respect." Defer, MERRIAM-WEBSTER ONLINE, http://www.merriam-webster.com/dictionary/defer (last visited Sept. 13, 2016).

8 For a definition of this standard of review, see infra note 59 and accompanying text. See also Amanda Peters, The Meaning, Measure, and Misuse of Standards of Review, 13 LEWIS \& CLARK L. REV. 233, 246 (2009) (arguing that the clear error and substantial evidence standards "are so similar in their wording and application, that many believe there really is very little, if any, difference between the two."); Perry A. Zirkel, Over-Due Process Revisions for the Individuals with Disabilities Education Act, 55 MONT. L. REV. 403, 410 (1994) (advocating for adoption of the substantial evidence standard for judicial review of IDEA hearing decisions).

${ }^{9}$ See E.F. ex rel. N.R. v. N.Y.C. Dep't of Educ., No. 11 CIV. 5243 GBD FM, 2014 WL 1092847, at*1 (S.D.N.Y. Mar. 17, 2014) (school district responsible for $\$ 286,062.50$ in tuition reimbursement and $\$ 110,343.51$ in attorneys' fees); A.R. v. N.Y.C. Dep't of Educ., No. 12 CIV. 7144, 2014 WL 5462465, at *1, *11 (S.D.N.Y. Oct. 28, 2014) (\$217,388.25 awarded in attorneys' fees for tuition reimbursement claim; parties reached settlement over tuition costs of $\$ 129,080.30$ ). 
seminal opinion in Town of Burlington v. Dep't of Ed. of Com. of Mass (Burlington II). Part V discusses the majority and minority approaches adopted by the circuit courts of appeal following Rowley. Part VI recommends a deference standard that is consistent with Rowley and employed by a minority of circuit courts. Part VII offers a brief conclusion.

\section{THE IDEA}

The IDEA is a federal law that provides financial assistance to states that make a Free and Appropriate Public Education (FAPE) available to students with disabilities. ${ }^{10}$ Once a state elects to receive federal funds under the IDEA, it must comply with the Act's numerous requirements, the most significant of which are summarized below. ${ }^{11}$ First, states must locate children with disabilities. $^{12}$ Having done so, school districts are required to evaluate students to determine if they are eligible for special education. $^{13}$ If a child is deemed eligible, the school district must convene a team to develop an Individualized Education Plan (IEP) for the student. ${ }^{14}$ The IEP identifies pertinent information about the student, including his or her current levels of academic achievement and functional performance. ${ }^{15}$ From these levels, the IEP team must generate annual goals for the student in each of his or her areas of need. ${ }^{16}$ An IEP team must also recommend educational services for students including a placement; i.e., the type of class the student will attend. ${ }^{17}$ The student's placement must be in the "least restrictive

${ }^{10} 20$ U.S.C. $\S 1400(d)(1)(A)$ (2012). See generally 20 U.S.C. $\S \S 1400-1482$.

${ }^{11}$ See generally 20 U.S.C. $\S \S 1414,1415$.

$12 \S 1412(\mathrm{a}) ; 34$ C.F.R. $\S 300.111$ (2006).

13 The IDEA identifies 10 categories of eligibility; students must satisfy the regulatory definition of at least one of these categories. 20 U.S.C. $\S 1401$ (3)(A).

${ }^{14} \S 1414(d)$.

$15 \S 1414(\mathrm{~d})(1)(\mathrm{A})(\mathrm{i})$.

1620 U.S.C. $\S 1414(d)(1)(A)(i)(I I)(2012)$.

$17 \S 1414(\mathrm{e}) . \quad$ "Placement," as used in the IDEA, refers to a student's educational program, and not a physical location; see, e.g., T.Y. v. N.Y.C. Dep't of Educ., 584 F.3d 412, 419 (2d Cir. 2009); White ex rel. White v. Ascension Par. Sch. Bd., 343 F.3d 373, 379 (5th Cir. 2003); James v. District of Columbia, 949 F. Supp. 2d 134, 137-38 (D.D.C. 2013). 
environment," meaning the environment that will provide the student with the greatest amount of access to nondisabled peers. ${ }^{18}$ IEPs serve as educational blueprints for students and are reviewed on a yearly basis. $^{19}$

Parents who do not agree with school districts' recommendations have a variety of options available under the IDEA. ${ }^{20}$ They may request that the school district conduct an independent educational evaluation, which the school district may have to pay for. ${ }^{21}$ They may engage in mediation. ${ }^{22}$ They may present a complaint to a state department of education for investigation. ${ }^{23}$ And, as relevant to this article, parents may commence an administrative proceeding by filing a document called a due process complaint notice. ${ }^{24}$ The notice must identify all of the parents' specific grievances as well as a proposed resolution to the problem. ${ }^{25}$

In designing the IDEA, Congress divided rulemaking and adjudicative responsibilities between two institutions, delegating rulemaking authority to the United States Department of Education's Office of Special Education Programs and recognizing that state departments of education would exercise adjudicative duties. ${ }^{26}$ This

1820 U.S.C. $\S 1412(\mathrm{a})(5)(\mathrm{A})$. However, the needs of the student are the paramount consideration; thus, it may be necessary to place a student in a selfcontained class or residential setting with no access to nondisabled peers; see M.W. ex rel. S.W. v. N.Y.C. Dep't of Educ., 725 F.3d 131, 143 (2d Cir. 2013).

${ }^{19} 20$ U.S.C. $\$ 1414(\mathrm{~d})(4)(\mathrm{A})(2012)$.

${ }^{20}$ See 20 U.S.C. $\$ 1415$ (f)(3)(E)(iii) (2012) (administrative injunctive relief); $\S$ 1415(b)(1); 34 C.F.R. $\S 300.502(b) \quad(2006)$ (independent educational evaluations); 20 U.S.C $\S 1412(a)(10)(C)(i i)$ (2012); 34 C.F.R. $\S 300.148(c)$ (2006) (tuition reimbursement). Additionally, school districts may (or must) file a due process complaint notice under certain circumstances. 20 U.S.C. $\S 1415(\mathrm{~b})(7)(\mathrm{A})$ (2012); see also I.R. ex rel. E.N. v. L.A. Unified Sch. Dist., No. 13-56211, 2015 WL 7253495 (9th Cir. Nov. 17, 2015).

${ }^{21} 20$ U.S.C. $\S 1415$ (b)(1); 34 C.F.R. $\S 300.502(b)$.

2220 U.S.C. $\$ 1415(\mathrm{~b})(5),(\mathrm{e}) ; 34$ C.F.R. $\$ 300.506(\mathrm{~b})$.

2334 C.F.R. $\$ 300.151-.153$. If the investigation reveals non-compliance with the IDEA, a state education department may issue a corrective order. 34 C.F.R. $\S \S$ 300.151(b), 300.152(a)(1), (5).

2420 U.S.C. $\$ 1415(\mathrm{~b})(7)(\mathrm{A})$.

${ }^{25} \S \S 1415(\mathrm{~b})(7)(\mathrm{A}),(\mathrm{c})(2)(\mathrm{A}),(\mathrm{f})(3)(\mathrm{B})$.

26 See 20 U.S.C. § 1402(a) (2012) ("There shall be, within the Office of Special Education and Rehabilitative Services in the Department of Education, an 
allocation embodies the principle of cooperative federalism, a system where "a federal statute provides for state regulation or implementation to achieve federally proscribed policy goals." 27 Cooperative federalism allows states to create novel solutions, which are responsive to local conditions in a way that a unitary federal standard cannot be. ${ }^{28}$

The IDEA requires state departments of education to provide parents with "an opportunity for an impartial due process hearing . . . ."29 These impartial hearings constitute a system of formal adjudication, an adversarial process resembling a simplified version of a trial. ${ }^{30}$ Formal adjudication affords parties "an opportunity to present their own and attack the [opposing side's] evidence and arguments before an official body with authority to decide the controversy." 31 The IDEA requires that parties appearing at such a hearing be allowed "to present evidence and confront, cross-examine, and compel the attendance of witnesses." 32 Additionally, parties may choose to be represented by counsel or an individual with specialized experience. $^{33}$ At the conclusion of the impartial hearing, an

Office of Special Education Programs, which shall be the principal agency in the Department for administering and carrying out this chapter and other programs ... .').

27 Philip J. Weiser, Towards A Constitutional Architecture for Cooperative Federalism, 79 N.C. L. REV. 663, 668 (2001); see also Philip J. Weiser, Federal Common Law, Cooperative Federalism, and the Enforcement of the Telecom Act, 76 N.Y.U. L. REV. 1692, 1703 (2001).

${ }^{28}$ Weiser, Federal Common Law, supra note 27, at 1698-1703.

${ }^{29} 20$ U.S.C. $\S 1415(\mathrm{f})(1)(\mathrm{A})$.

${ }^{30}$ See Thomas Moore, Abandoning Mead: Why Informal Adjudications Should Only Receive Minimal Deference in Federal Courts, 2008 UTAH L. REV. 719, 724 (2008); see also Melissa M. Berry, Beyond Chevron's Domain: Agency Interpretations of Statutory Procedural Provisions, 30 SEAtTle U. L. ReV. 541, 549, n.51 (2007)., See generally id. at, 547. Agencies may also engage in "informal adjudication," which encompasses "a huge range of procedures" utilized by agencies to determine rights. Moore, supra, at 724.

31 1941 Final Rep. Of The AtT'y Gen. Comm. Admin. Proc. 43 (1941).

3220 U.S.C. $\S 1415(\mathrm{~h})(2)(2012)$.

${ }^{33} \S 1415(\mathrm{~h})(1)$. 
administrative law judge, called a hearing officer, must issue a written decision resolving the parties' claims. ${ }^{34}$

Some states, as permitted by the IDEA, provide a second level of state administrative review. ${ }^{35}$ Under this procedure, a party may appeal to a State Review Officer (SRO) who conducts an "independent" review of the hearing record and ensures that due process was observed throughout the impartial hearing. ${ }^{36}$

Once the administrative review process has concluded, a party who is "aggrieved by the findings and decision" of a hearing officer or SRO, depending on the jurisdiction, may file a civil action in state or federal court. ${ }^{37}$ The IDEA identifies three additional requirements governing judicial review of IDEA disputes. First, a court "shall receive the records of the administrative proceedings." 38 Second, the court "shall hear additional evidence at the request of a party." 39 Third, the court "shall grant such relief" that it determines to be appropriate based upon "the preponderance of the evidence." 40

The IDEA's judicial review provision is not a model of clarity. ${ }^{41}$ While it imposes a "preponderance of the evidence" standard-a test

${ }^{34} \S 1415(\mathrm{~h})(4)$. The IDEA refers to the administrative law judge as a hearing officer in numerous places throughout the statute, see, e.g., $\S 1415(\mathrm{c})(2)(\mathrm{A})$, (f)(3)(E).

$35 \S 1415(\mathrm{~g})(2) ; 34$ C.F.R. $\S 300.511(\mathrm{~b})$ (An impartial hearing "must be conducted by the [state educational agency] or the public agency directly responsible for the education of the child, as determined under [s]tate statute, [s]tate regulation, or a written policy of the [state educational agency]").

3620 U.S.C. $\S 1415(\mathrm{~g})(2)$; 34 C.F.R. $\S 300.514(\mathrm{~b})(2006)$. States use various initials or acronyms to refer to these administrative officials; "SRO" is used throughout this article for consistency. See, e.g., Horen v. Bd. of Educ. of City of Toledo Pub. Sch., 950 F. Supp. 2d 946, 947 (N.D. Ohio 2013) (State Level Review Officer); Indep. Sch. Dist. No. 283, St. Louis Park, Minn. v. S.D. By \& Through J.D., 948 F. Supp. 860, 869 (D. Minn. 1995), aff'd sub nom. Indep. Sch. Dist. No. 283 v. S.D. by J.D., 88 F.3d 556 (8th Cir. 1996) (Hearing Review Officer).

3720 U.S.C. $\$ 1415(\mathrm{i})(2)(\mathrm{A})(2012)$.

${ }^{38} \S 1415(\mathrm{i})(2)(\mathrm{C})(\mathrm{i})$.

$39 \S 1415(\mathrm{i})(2)(\mathrm{C})(\mathrm{ii})$.

$40 \S 1415(\mathrm{i})(2)(\mathrm{C})(\mathrm{iii})$.

41 The Sixth Circuit said it best: "[w]hile the focus of the inquiry is clear, the appropriate standard of review is more elusive." Thomas v. Cincinnati Bd. of Educ., 918 F.2d 618, 624 (6th Cir. 1990) (overturned on other grounds); see also Andriy Krahmal et. al., "Additional Evidence" Under the Individuals with Disabilities Education Act: The Need for Rigor, 9 TEX. J. C.L. \& C.R. 201, 204 
requiring a litigant prove that "[t]he greater weight of the evidence" supports his or her claims - this is a standard of proof, not a standard of deference. ${ }^{42}$ In other words, preponderance of the evidence relates to how much proof the party seeking relief in court must produce, while deference pertains to how much weight must be afforded to the conclusions of prior (i.e., state administrative) proceedings.

Moreover, the IDEA does not distinguish between the two forms of judicial review, trial and appellate, that an IDEA action can undergo. ${ }^{43}$ The trial stage, however, is the crucial stage of review, as the courts of appeal generally use the district court's decision as a frame of reference. Most courts of appeal apply either the same deference standard employed by the trial court ${ }^{44}$ or the traditional standards of deference for factual (clear error/substantial evidence) and legal (de novo) determinations made by the trial court. ${ }^{45}$

(2004) (the IDEA “is silent about . . the standard of review . . . " [i.e., degree of deference]).

${ }^{42}$ Preponderance of the Evidence, Black's Law Dictionary (10th ed. 2014).

${ }^{43}$ See generally Thomas F. Guernsey, When The Teachers and Parents Can't Agree, Who Really Decides? Burdens of Proof and Standards of Review Under the Education for all Handicapped Children Act, 36 CLEV. ST. L. REV. 67, 77-93 (1987). Another complication, not addressed by the IDEA, is the degree of deference an SRO owes to the decision of a hearing officer. See Perry A. Zirkel, The Standard of Review Applicable to Pennsylvania's Special Education Appeals Panel, 3 WIDENER J. PUB. L. 871, 874 (1994). Professor Zirkel proposed deference to a hearing officer's factual findings but no deference for legal issues and mixed questions of law and fact (with two exceptions). Id. at 892. Professor Zirkel also proposed that an SRO's acceptance and consideration of additional evidence would result in de novo review of the additional evidence. Id. at 891, n.99. A recent district court decision held that an SRO's entire review is de novo. See C.R. v. N.Y. City Dep't of Educ., No. 15 CIV. 3051 (ER), 2016 WL 5793415, at*13 (S.D.N.Y. Sept. 30, 2016) ("the SRO's review of an IHO's decision is ... intended to be de novo").

${ }^{44}$ See O.S. v. Fairfax Cty. Sch. Bd., 804 F.3d 354, 360 (4th Cir. 2015); Garcia v. Bd. of Educ. of Albuquerque Pub. Sch., 520 F.3d 1116, 1125 (10th Cir. 2008); Draper v. Atlanta Indep. Sch. Sys., 518 F.3d 1275, 1284 (11th Cir. 2008).

45 See N.W. ex rel. J.W. v. Boone Cty. Bd. of Educ., 763 F.3d 611, 615 (6th Cir. 2014); R.L. v. Miami-Dade Cty. Sch. Bd., 757 F.3d 1173, 1181 (11th Cir. 2014); Klein Indep. Sch. Dist. v. Hovem, 690 F.3d 390, 394 (5th Cir. 2012); Upper Freehold Reg'l Bd. of Educ. v. T.W., 496 F. App'x 238, 242 (3d Cir. 2012); C.G. ex rel. A.S. v. Five Town Cmty. Sch. Dist., 513 F.3d 279, 284 (1st Cir. 2008); Pachl v. Seagren, 453 F.3d 1064, 1068 (8th Cir. 2006); Alex R., ex rel. Beth R. v. Forrestville Valley Cmty. Unit Sch. Dist. No. 221, 375 F.3d 603, 612 (7th Cir. 
Additionally, while all circuits agree that a district court's receipt of additional evidence alters the deference calculus, they do not agree as to its precise effect. ${ }^{46}$

The House version of the IDEA contained a more straightforward judicial review provision, providing that "the findings of fact of the State educational agency shall be conclusive if supported by substantial evidence ...." ${ }^{97}$ It also gave district courts the authority to "remand the case to the State agency to take additional evidence." 48 The Senate, however, altered (or, according to the Senate Conference report, "clarified and strengthened") this language by substituting the present text with one exception: the Senate Conference report indicated that a state or federal court must render an "independent decision." ${ }^{4}$ This phrase was not included in the final version of the IDEA.

2004); Amanda J. ex rel. Annette J. v. Clark Cty. Sch. Dist., 267 F.3d 877, 887 (9th Cir. 2001). A minority of Circuits review the entire proceeding de novo; see M.O. v. N.Y.C. Dep't of Educ., 793 F.3d 236, 243 (2d Cir. 2015); Reid ex rel. Reid v. District of Columbia, 401 F.3d 516, 522 (D.C. Cir. 2005).

${ }^{46}$ See, e.g., M.H. v. N.Y.C Dep't of Educ., 685 F.3d 217, 244 (2d Cir. 2012) (less deference to district court if it accepted additional evidence); Alex R., ex rel. Beth R. v. Forrestville Valley Cmty. Unit Sch. Dist. No. 221, 375 F.3d 603, 612 (7th Cir. 2004) (sliding scale of deference if additional evidence accepted: "[t]he more that the district court relies on new evidence, however, the less it should defer to the administrative decision . ..."); S.H. v. State-Operated Sch. Dist. of City of Newark, 336 F.3d 260, 270 (3d Cir. 2003) (district court reviews additional evidence do novo and is "free to accept or reject the agency findings depending on whether those findings are supported by the new, expanded record and whether they are consistent with the requirements of the Act.") (quoting Carlisle Area Sch. v. Scott P., 62 F.3d 520, 527 (3d Cir. 1995)); M.M. ex rel. D.M. v. Sch. Dist. of Greenville Cty., 303 F.3d 523, 531 (4th Cir. 2002) ("where a district court has heard and considered additional evidence ... we review its findings of fact for clear error"); Reid, 401 F.3d at 522 (had district court accepted additional evidence, the court's "review [of the district court] would be deferential — clear error as to any factual findings and abuse of discretion as to the remedy."). See generally Krahmal et. al., supra note 41, at 215 (detailed review of Circuit Courts' standards for accepting additional evidence revealed "a broad spectrum of opinions that reflect and advance confusion about the appropriate standard").

47 S. CONF. REP. No. 94-455 at 47-48 (1975), as reprinted in 1975 U.S.C.C.A.N. 1480, 1501.

${ }^{48} \mathrm{Id}$. at 48 .

${ }^{49}$ S. CONF. REP. No. 94-455 at 1502. 
The House and Senate versions, while diametrically opposed, offered clear views. The House version called for the traditional deference owed to administrative decisions, while the Senate endorsed de novo review. But, the final text offered a confusing mixture of both approaches. ${ }^{50}$

\section{JUDICIAL REVIEW OF AgENCY ADJUDICATION}

The IDEA's muddled judicial review provision contrasts sharply with the ordinary rules governing judicial review of agency adjudication. But before exploring these rules, it is necessary to briefly describe the nature and structure of administrative agencies. When Congress creates a law, it may identify or create an agency that will be responsible for implementing the law. ${ }^{51}$ Once created, agencies may be given broad powers. A single agency may, for example, issue rules, investigate, prosecute complaints, and decide matters between opposing parties (i.e., adjudicate). ${ }^{52}$ An agency's two most critical duties are rulemaking and adjudication. ${ }^{53}$

Agency adjudication, which includes IDEA impartial hearings, is subject to judicial review. Courts have long concluded that courts reviewing the decisions of administrative agencies owe deference to administrators' conclusions; commentators have discerned a tradition of judicial deference dating back to the nineteenth-century. ${ }^{54}$ Deference means that courts must accept an agency or lower court's

50 See Susan G. Clark, Judicial Review and the Admission of "Additional Evidence" Under the IDEIA: An Unusual Mixture of Discretion and Deference, 201 ED. LAW REP. 823, 827-28 (2005); Guernsey, supra note 43, at 77-93. One is reminded of the old saw that a camel is a horse designed by committee.

51 The Supreme Court has held that Congress must provide an "intelligible principle" when delegating its authority in this manner. Dee Whitman v. Am. Trucking Ass'n, 531 U.S. 457, 472-73 (2001).

52 This summary is based on an analysis by Justice Robert H. Jackson. See Robert H. JACKSON, THE Supreme COURT IN THE AMERICAN System OF GOVERNMENT 44 (1955).

${ }^{53}$ Berry, supra note 30 , at 547.

${ }^{54}$ Kristin E. Hickman and Matthew D. Krueger, In Search of the Modern Skidmore Standard, 107 ColuM. L. REV. 1235, 1239 (2007); see also Antonin Scalia, Judicial Deference to Administrative Interpretations of Law, 1989 DUKE L.J. 511, 512 (1989). 
conclusions even if the court would have reached a different result. ${ }^{55}$ Courts use a wide variety of linguistic formulations to describe the amount of deference owed under particular circumstances. Indeed, one commentator catalogued thirty different formulations used by state and federal courts. ${ }^{56}$ Professor Amanda Peters has helpfully condensed these into three standards, presented in order of most to least deferential: (1) abuse of discretion (great deference); (2) clearly erroneous/substantial evidence (moderate deference); and (3) de novo $^{57}$ (no deference). ${ }^{58}$

Given its relevance to judicial review of IDEA administrative decisions, the substantial evidence standard requires further explanation. A long-standing phrase, it was adopted as the judicial review standard for formal adjudication in the Administrative Procedure Act (APA) in 1946. ${ }^{59}$ The Supreme Court has stated that substantial evidence "means such relevant evidence as a reasonable mind might accept as adequate to support a conclusion." 60 Therefore, this standard requires a court to accept an agency's reasonable

55 As a colloquial matter, Black's Law Dictionary's second definition of "deference" is apt: "[a] polite and respectful attitude or approach, esp. toward an important person or venerable institution whose action, proposal, opinion, or judgment should be presumptively accepted." Deference, Black's Law Dictionary (10th ed. 2014).

${ }^{56}$ Richard H. W. Maloy, 'Standards of Review' - Just A Tip of the Icicle, 77 U. Det. MerCy L. ReV. 603, 610 (2000).

${ }^{57}$ De novo is Latin for "anew." De novo, Black's Law Dictionary (10th ed. 2014). Thus, a court reviewing a dispute "anew" would owe no deference to a prior decision maker.

${ }^{58}$ Amanda Peters, The Meaning, Measure, and Misuse of Standards of Review, 13 LEWIS \& ClARK L. REV. 233, 242-46 (2009). While Professor Peters identified four standards, she persuasively argues that any difference between the "clearly erroneous" and "substantial evidence" standards is academic. Therefore, I have condensed her four standards into three.

${ }^{59}$ See 5 U.S.C. $§ 706$ (2012) ("The reviewing court shall ... hold unlawful and set aside agency action, findings, and conclusions found to be . . . unsupported by substantial evidence in a case subject to sections 556 and 557 of this title ....") Sections 556 and 557 outline procedures for hearings which, in turn, refer to sections 553 and 554 on rulemaking and adjudication. See 5 U.S.C. $\S \S 506,507$ (2012).

${ }^{60}$ Consol. Edison Co. of New York v. N.L.R.B., 305 U.S. 197, 229 (1938); see also Substantial-Evidence Rule, Black's Law Dictionary (10th ed. 2014). 
conclusion. $^{61}$ Implicit in this rule is that, in many instances, one or more conclusions may be drawn from the same evidence.

But why should courts defer to the conclusions of administrative agencies? Commentator Bradley Lipton has summarized three reasons offered by the U.S. Supreme Court. ${ }^{62}$ The first is expertise: administrative agencies are specialists, while courts are generalists. ${ }^{63}$ Second, Congress or a state legislature delegated its authority to the agency to administer the act in question; thus, the agency acts with the blessing of the Legislative Branch. ${ }^{64}$ Third, agencies are political branches that, unlike the judiciary, can be held directly accountable for their actions. ${ }^{65}$ As former Supreme Court Justice Robert H. Jackson put it, federal agencies "are dependent for annual appropriations on Congress, which appropriately can inquire whether its policies are being carried out according to its interest." 66

Judicial review of agency adjudication draws a distinction between fact and law, and courts give deference to administrative

${ }^{61}$ Anderson v. City of Bessemer City, N.C., 470 U.S. 564, 573 (1985) ("This standard plainly does not entitle a reviewing court to reverse the finding of the trier of fact simply because it is convinced that it would have decided the case differently."); see also Womble v. Pher Partners, 299 B.R. 810, 812 (N.D. Tex. 2003) aff'd sub nom. In re Womble, 108 F. App'x 993 (5th Cir. 2004) ("Under the clearly erroneous standard of review, if there are two coherent and facially plausible views of testimonial evidence and one is adopted, and it is not contradicted by extrinsic evidence, the finding can virtually never be clearly erroneous.").

${ }^{62}$ Bradley Lipton, Accountability, Deference, and the Skidmore Doctrine, 119 YALE L.J. 2096, 2120-21 (2010).

${ }^{63}$ Id. at 2121. But see David Zaring, Reasonable Agencies, 96 VA. L. REV. 135, 196 (2010) ("[C]ourts, in practice, give agencies some flexibility in performing the tasks with which they have been charged; the basis for the flexibility appears to lie less in administrative puissance and more in the legal choice by Congress to invest agencies with decisionmaking powers."); Scalia, supra note 54, at 514 ("If it is, as we have always believed, the constitutional duty of the courts to say what the law is, we must search for something beyond relative competence as a basis for ignoring that principle when agency action is at issue.") (emphasis omitted).

${ }^{64}$ Lipton, supra note 62, at 2121.

${ }^{65} \mathrm{Id}$. at 2122.

${ }^{66}$ JACKSON, supra note 49, at 49. 
findings regarding the former but not the latter. ${ }^{67}$ This distinction was carried over from the judiciary, where juries make findings of fact and courts decide issues of law. ${ }^{68}$ The rationale for the rule is that jurors (or administrators) personally observed the witnesses who appeared before them and are in the best position to evaluate their credibility, while law remains the province of the court. ${ }^{69}$

The fact/law distinction, however, is not as clear-cut as it initially appears. $^{70}$ While examples are easy to imagine-whether an individual signed a contract is a question of fact, but whether a contract is valid under the statute of frauds is an issue of law-the relationship between fact and law is complex. ${ }^{71}$ Recognizing this ambiguity, courts have resorted to describing certain issues as "mixed questions of law and fact."72 How to treat such issues has produced no shortage of confusion; commentator Randall H. Warner describes mixed questions as "a sort of catch-all, an amorphous box into which courts place any issue or combination of issues that cannot neatly be labeled law or fact." 73 Accordingly, state and federal courts have reached differing conclusions as to whether mixed questions should receive deference and, if so, how much. ${ }^{74}$

67 See Louis L. Jaffe, Judicial Review: Question of Fact, 69 HARV. L. REV. 1020 (1956); Ray A. Brown, Fact and Law in Judicial Review, 56 HARV. L. REV. 899 (1943); Rep. Att'y Gen. Comm. Ad. Proc. 88 (1941).

${ }^{68}$ Randall H. Warner, All Mixed Up About Mixed Questions, 7 J. APP. PraC. \& PROCESS 101, 104-05 (2005).

${ }^{69}$ Warner, supra note 68, at 104 (2005).

${ }^{70}$ See Brown, supra note 67 , at 899 n.3.

${ }^{71}$ See, e.g., Adrian A. S. Zuckerman, Law, Fact or Justice?, 66 B.U. L. REV. 487, 488 (1986) (“[Q]uestions of law . . . are frequently treated as questions of fact. Furthermore, ... questions concerned with the process of ascertaining the facts sometimes receive the kind of treatment usually accorded to questions of law."); Clarence Morris, Law and Fact, 55 HARV. L. REV. 1303, 1304 (1942) ("The naive assumption that law and fact stand naturally apart draws attention away from the role that law plays in the selection and description of facts, and that facts play in impelling the adoption of rules and in limiting the scope of their application.").

${ }^{72}$ See, e.g., Warner, supra note 65, at 101; see also John R. Knight, All Mixed Up-the Fifth Circuit's Standard of Review for Mixed Questions of Fact and Law, 10 App. Advoc. 3 (1997).

${ }^{73}$ Warner, supra note 68, at 102.

${ }^{74} \mathrm{Id}$. at 107. 


\section{ROWLEY AND BURLINGTON}

\section{A. Board of Education of the Hendrick Hudson Central School District v. Rowley}

In 1982, the Supreme Court tackled the daunting task of discerning a deference standard from the IDEA's judicial review provision in Board of Education of the Hendrick Hudson Central School District v. Rowley. ${ }^{75}$ Rowley is best known for interpreting the word "appropriate" as used in the IDEA to mean "reasonably calculated to enable [a student] to receive educational benefits." 76 However, Rowley is also significant for its holding concerning the degree of deference federal courts owe to state administrative proceedings.

Rowley centered on whether a deaf student required a sign language interpreter in order to receive a FAPE. ${ }^{77}$ The school district offered the provision of an "FM hearing aid," a device that would "amplify words spoken into a wireless receiver by the teacher or fellow students during certain classroom activities." however, maintained that the student required a classroom sign language interpreter. ${ }^{79}$ A hearing officer and an SRO agreed with the school district, finding that the student made educational, academic, and social achievements without use of the interpreter. ${ }^{80}$

The district court, which reversed the conclusions of the hearing officer and SRO, did not afford any deference to the administrative proceedings. ${ }^{81}$ Indeed, as the Second Circuit noted, the district court

75458 U.S. 176 (1982).

${ }^{76}$ Id. at 177. See also O.S. v. Fairfax Cty. Sch. Bd., 804 F.3d 354 (4th Cir. 2015); Endrew F. ex rel. Joseph F. v. Douglas Cty. Sch. Dist. Re-1, 798 F.3d 1329, 1339 (10th Cir. 2015), cert. granted, No. 15-827, 2016 WL 5416228 (U.S. Sept. 29,2016 ) (holding that Rowley's FAPE standard remains binding law).

${ }^{77}$ Rowley, 458 U.S. at 184-85.

${ }^{78} \mathrm{Id}$. at 184 .

${ }^{79} \mathrm{Id}$.

${ }^{80} \mathrm{Id}$. Another salient piece of evidence was that a sign language interpreter provided by the school district during the student's previous (kindergarten) school year concluded, after two weeks, that the student did not require her services. Id.

${ }^{81}$ Rowley v. Bd. of Educ. of Hendrick Hudson Cent. Sch. Dist., 483 F. Supp. 528 (S.D.N.Y. 1980). Prior to 1990, appeals of IDEA hearing officer decisions were issued by New York's Commissioner of Education. See Heldman on Behalf 
held a trial where it entertained additional testimony. ${ }^{82}$ The Second Circuit briefly affirmed the conclusions of the district court. ${ }^{83}$ The Supreme Court granted certiorari and, before turning to the merits of the case, addressed the issue of administrative deference in detail.

The Court began by noting the divergent arguments of the parties: the school district argued that the Court had "limited authority" to review the determinations of administrative officers, while the parent contended that a court was obligated to conduct de novo review. ${ }^{84}$ The Court rejected both of these arguments. ${ }^{85}$ Addressing the school district's position, the Court stated that the ordinary, deferential standard of review afforded administrative decisions would be inappropriate because Congress considered and rejected the substantial evidence standard. ${ }^{86}$ As for the parents' argument, the Court stated that the preponderance of the evidence language in the judicial review provision did not constitute an "invitation to the courts to substitute their own notions of sound educational policy for those of the school authorities which they review." 87 The answer, the Court concluded, lay somewhere between the parties' positions. ${ }^{88}$

In determining the extent of deference owed to administrative officers, the Court concluded that it could not be gleaned from the IDEA's judicial review provision alone. ${ }^{89}$ Instead, the Court

of T.H. v. Sobol, 962 F.2d 148, 152 n.5 (2d Cir. 1992). New York State created the Office of State Review in 1990 and assigned to it the IDEA duties formerly exercised by the Commissioner of Education. See id. ("Effective July 1, 1990, a state review officer, instead of the Commissioner of Education, reviews the initial hearing."). Decisions rendered by the Commissioner have been referred to as SRO decisions for purposes of clarity.

82 See Rowley v. Bd. of Ed. of Hendrick Hudson Cent. Sch. Dist., 632 F.2d 945, 951 (2d Cir. 1980).

${ }^{83}$ Id. at 946-48. The Second Circuit's opinion also contains a dissent by Judge Mansfield criticizing the majority's reasoning and articulating several of the arguments adopted by the Supreme Court in Rowley. Id. at 948-54 (Mansfield, J., dissenting).

${ }^{84}$ Board of Educ. of Hendrick Hudson Central School Dist., Weschester Cty. v. Rowley, 458 U.S. 176, 205 (1982).

${ }^{85} \mathrm{Id}$. at $205-07$.

${ }^{86} \mathrm{Id}$. at 205.

${ }^{87} \mathrm{Id}$. at 206.

${ }^{88} I d$.

${ }^{89} \mathrm{Id}$. 
consulted the overall structure of the IDEA. ${ }^{90}$ According to the Court, the IDEA assigned "primary responsibility for developing and executing educational programs" to the states. ${ }^{91}$ Moreover, the Court reasoned that because the IDEA is a funding statute intended to assist States in promoting access to their public school systems, it ensures only a "basic floor of opportunity" to students with disabilities. ${ }^{92}$

With these considerations in mind, the Court held that courts must give "due weight" to administrative proceedings. ${ }^{93}$ The Court did not define the standard, other than to suggest that it fell somewhere in-between the deferential substantial evidence standard and the non-deferential de novo standard. ${ }^{94}$ The beauty of the phrase "due weight" is that, while often recited by courts, its precise definition is elusive. ${ }^{95}$ Other aspects of the Court's analysis, however, provide clues as to its meaning in this context.

${ }^{90}$ Board of Educ. of Hendrick Hudson Central School Dist., Weschester Cty. v. Rowley, 458 U.S. 176, 206-07 (1982).

${ }^{91} I d$. at 183.

${ }^{92} \mathrm{Id}$. at 200. This approach is generally consistent with the philosophy of its author, former Chief Justice William Rehnquist. See Jeff Powell, The Compleat Jeffersonian: Justice Rehnquist and Federalism, 91 YALE L.J. 1317 (1982).

93 Rowley, 458 U.S. at 206. The phrase "due weight" has a long historical pedigree. See, e.g., Boone v. Chiles, 35 U.S. 177, 248 (1836); Clark's Ex'rs v. Van Riemsdyk, 13 U.S. 153, 161 (1815); The Alexander, 12 U.S. 169, 174 (1814). The Supreme Court has, in modern times, used due weight to describe a degree of deference owed to lower court proceedings. See Wong Sun v. United States, 371 U.S. 471, 479 (1963) (due weight given to the court of appeals' conclusion that "there was neither reasonable grounds nor probable cause" for an arrest).

${ }^{94}$ Chief Justice Rehnquist attempted this same conceptual feat twelve years later in Ornelas v. United States. See 517 U.S. 690, 700, 705 (1996) (Scalia, J., Dissenting) (criticizing a majority opinion authored by Chief Justice Rehnquist holding that, in the context of a Fourth Amendment claim, an appellate court should apply de novo review but "give due weight to a trial court's finding that the officer was credible and the inference was reasonable." Justice Scalia countered by arguing that: "[t]he Court cannot have it both ways. This finding of 'reasonableness' is precisely what it has told us the appellate court must review de novo; and in de novo review, 'the weight due' to a trial court's finding is zero.") (emphasis omitted).

95 See, e.g., Terry v. Ohio, 392 U.S. 1, 26 (1968) (holding that "due weight must be given" to a police officer's "specific reasonable inferences which he [or she] is entitled to draw from the facts in light of his [or her] experience" in context of Fourth Amendment search); Louisiana Power \& Light Co. v. Roberts, 408 So. 2d 49, 51 (La. Ct. App. 1981) cert. denied sub nom. Louisiana Power \& Light Co. 
In explaining why deference would be appropriate, the Court stated that "courts lack the 'specialized knowledge and experience' necessary to resolve "persistent and difficult questions of educational policy" and enjoined courts "to avoid imposing their view of preferable educational methods upon the States." 96 This suggests that due weight applies to educational policy determinations made by state administrators. A further elucidation of the due weight standard can be discerned from the Court's contrast between the procedural and substantive provisions of the IDEA. On one hand, the Court observed that the IDEA's procedural protections were "elaborate," "highly specific," and of the utmost importance to Congress. ${ }^{97}$ Indeed, reasoned the Court, Congress placed equal emphasis on procedural compliance as it did on substantive outcomes, i.e., whether or not an IEP was "appropriate." 98 On the other hand, the Court observed that the substantive standards in the IDEA were "general and somewhat imprecise." 99 Therefore, the Court concluded that the IDEA intended to achieve substantive outcomes vis-à-vis its procedural protections. ${ }^{100}$ In other words, if a school district followed the IDEA's checklist of procedures, the resulting IEP should offer a FAPE.

On the merits of the case, the Court held that the school district's program offered "personalized instruction and related services calculated . . . to meet [the student's] educational needs," and that

v. Roberts, 412 So. 2d 1111 (La. 1982) (due weight owed "to opinions and conclusions of experts," especially under certain circumstances); Foster v. Evans, 384 Mass. 687, 698 (1981) (probate judge's findings regarding fraudulent concealment given "due weight" and "will not be reversed unless plainly wrong.") (quoting Bianchi v. Retirement Bd. of Somerville, 359 Mass. 642, 644 (1971)); Sopiarz v. ITT Life Ins. Corp., N.W.2d 364 (Ct. App. 1981) (affording due weight to trial court's assessment of witness credibility).

${ }^{96}$ Board of Educ. of Hendrick Hudson Central School Dist., Weschester Cty. v. Rowley, 458 U.S. 176, 207-08 (1982) (quoting San Antonio Indep. Sch. Dist. v. Rodriguez, 411 U.S. 1, 42 (1973)).

${ }^{97}$ Rowley, 458 U.S. at 205.

${ }^{98} I d$. at $205-06$.

${ }^{99} \mathrm{Id}$. at 205.

${ }^{100} I d$. at 206 ("[A]dequate compliance with the procedures prescribed would in most cases assure much if not all of what Congress wished in the way of substantive content in an IEP."). 
this constituted a FAPE. ${ }^{101}$ The Court also observed that the student "perform[ed] better" than most students in her class, and "easily" advanced from grade to grade. ${ }^{102}$ Thus, the Court concluded that the lower courts erred by reversing the hearing officer and SRO. ${ }^{103}$

Subsequent judicial interpretations of Rowley's deference standard have struggled with two questions. First, what exactly should a court give "due weight" to? Rowley referred to the "administrative proceedings," but this can consist of two decisions, both of which contain findings of fact and legal conclusions. Second, how much weight does "due weight" require? The First Circuit tackled both of these issues in a seminal decision, Town of Burlington v. Department of Education for the Commonwealth of Massachusetts (Burlington II), issued just two years after Rowley. ${ }^{104}$ The First Circuit read Rowley's deference discussion very narrowly, an approach that proved influential among the circuit courts. ${ }^{105}$

\section{B. Town of Burlington v. Department of Education for the Commonwealth of Massachusetts}

The procedural history of Burlington II is byzantine. For purposes of the present examination, it is necessary only to note that the parent and the school district disagreed as to whether a public or private school program would best meet the student's needs, ${ }^{106}$ and the parent enrolled the student in a private school while contemporaneously initiating a due process proceeding seeking tuition reimbursement from the school district. ${ }^{107}$ When the underlying dispute in Burlington II arose, Massachusetts state law provided that state courts must uphold administrative decisions

${ }^{101}$ Board of Educ. of Hendrick Hudson Central School Dist., Weschester Cty. v. Rowley, 458 U.S. 176, 210 (1982).

${ }^{102} \mathrm{Id}$.

${ }^{103} \mathrm{Id}$. at $209-10$.

104736 F.2d 773 (1st Cir. 1984).

${ }^{105}$ Burlington was also the first circuit court decision to consider the meaning of the IDEA's additional evidence provision. See Clark, supra note 50, at 828.

${ }^{106}$ See Town of Burlington v. Dep't of Educ. of Mass., 655 F.2d 428, 429 (1st Cir. 1981).

${ }^{107} \mathrm{Id}$. 
supported by substantial evidence. ${ }^{108}$ The parent prevailed at an administrative hearing, and the school district appealed to a federal district court asserting a claim under the IDEA as well as a pendent claim under Massachusetts state law. ${ }^{109}$ The federal district court applied the substantial evidence standard of review imposed by Massachusetts state law and granted summary judgment for the parent on his state law claim. ${ }^{110}$ In Burlington I, the First Circuit reversed, holding that the parent's appeal to federal court and invocation of the IDEA required an application of the IDEA's judicial review provision. ${ }^{111}$ The court noted that the federal review standard "seems . . . designed to occupy the field over an inconsistent state provision," but declined to consider whether this would apply to an aggrieved litigant who only sought review under the more deferential state standard. ${ }^{112}$ As further support for its decision, the court noted that the IDEA "directs ... the reviewing court [to] 'hear additional evidence' while the state provision normally confines its review to the record developed by the agency."113 The court found that this "present[ed] the specter of inconsistent federal and state judgments.", 114

Following multiple judicial decisions and an order that the parent reimburse the Town of Burlington for the private school tuition and related expenses, the parent appealed to the First Circuit a second time. ${ }^{15}$ The First Circuit issued Burlington II in 1984, this time equipped with the Supreme Court's guidance in Rowley.

Burlington II involved a host of "novel" issues, including "the weight to be accorded to the state administrative record and the hearing officer's findings upon appeal."116 Before delving into the issue of deference, the court generally observed that the IDEA

${ }^{108} I d$. at 431.

${ }^{109} \mathrm{Id}$. at $429-30$.

${ }^{110} I d$. at 430.

111 Town of Burlington v. Dep't of Educ. of Mass., 655 F.2d 428, 431 (1st Cir. 1981).

${ }^{112} I d$.

${ }^{113} I d$. at 432.

${ }^{114} \mathrm{Id}$.

115 Town of Burlington v. Dep't of Educ. for Com. of Mass., 736 F.2d 773, 779 (1st Cir. 1984).

${ }^{116} I d$. at 778 . 
imposes a system of "cooperative federalism." "117 This structure, the court explained, did not upend states' traditional authority to educate their citizens, and merely required that states provide a base level of services to students with disabilities. ${ }^{118}$ As support for this proposition, the court noted that the IDEA imposed "skeletal federal provisions" for impartial due process hearings, which states could supplement. ${ }^{119}$

Turning to the IDEA's judicial review provision, the First Circuit stated that "the key . . . lies in the additional evidence clause." 120 The court reasoned that if trial courts avoided widespread admission of additional evidence, this "structural []" approach would afford "due weight" to the state administrators because a court would examine the same record that was before the hearing officer or SRO. ${ }^{121}$ Liberal admission of additional evidence would, by contrast, amount to de novo review rather than the "something short of a trial de novo" called for by the IDEA. ${ }^{122}$ The court left the decision of whether to admit additional evidence to the discretion of trial courts. ${ }^{123}$

What about Rowley's injunction that the court must afford due weight to the "administrative proceedings"? ${ }^{124}$ Affording great significance to the fact that the IDEA and Rowley used the word "proceedings" and not "findings," the court concluded that the issue of deference to factual findings, like additional evidence, "must be left to the discretion of the trial court."125 As a consolation prize to parties seeking administrative deference, the court stated that a court

${ }^{117}$ Id. at $784-85$.

${ }^{118}$ Id. at 785 (Stating, "[w]e find no support in the legislative history of a congressional intention to supplant the states' historic direction of education within their boundaries.").

${ }^{119} I d$.

${ }^{120} \mathrm{Id}$. at 790 .

${ }^{121} I d$.

122 Town of Burlington v. Dep't of Educ. for Com. of Mass., 736 F.2d 773, 790 (1st Cir. 1984) (citations omitted). For a well-reasoned response to the Burlington II court's relatively liberal policy on admitting additional evidence, see Krahmal et. al., supra note 38 , at 224.

123 Town of Burlington v. Dep't of Educ. for Com. of Mass., 736 F.2d 773, 791 (1st Cir. 1984).

${ }^{124} \mathrm{Id}$. at 791 .

${ }^{125} \mathrm{Id}$. at $791-92$. 
"must consider the [administrative] findings carefully and endeavor to respond to the hearing officer's resolution of each material issue." "26 But, having done so, a court would be "free to accept or reject the findings in part or in whole."127 The court also stated that trial courts had the duty to render "independent" decisions. ${ }^{128}$ As noted above, the word "independent" was included in the Senate Conference Committee report but ultimately omitted from the final text of the IDEA. ${ }^{129}$

The Supreme Court granted certiorari in Burlington II, but only on two limited issues regarding the availability of tuition reimbursement as a remedy. ${ }^{130}$ The Supreme Court explicitly stated that it "express[ed] no opinion on any of the many other views stated by the court of appeals." 131 Thus, the Court left Burlington II's deference standard intact within the First Circuit.

The Burlington II Court's analysis departed from Rowley in two significant respects. First, while it distinguished fact from law, it did not address Rowley's distinction between procedure and substance. Second, Burlington II stripped "due weight"-which, in Rowley, prevented a court from ruling on the relative merits of two special education services - of any meaning. While the Court stated that district courts must mull over the state administrative findings, it gave them free reign to reject them. This narrow reading proved influential and supplanted the standard envisioned by the Rowley Court.

${ }^{126} I d$. at 792 .

${ }^{127} \mathrm{Id}$.

${ }^{128}$ Id. at 790-91.

${ }^{129}$ Id. Although Burlington II and Rowley cited the Conference Committee report, the phrase has taken on a life of its own. See M.H. v. N.Y. City Dep't of Educ., 685 F.3d 217, 240 (2d Cir. 2012) (characterizing independent review as a legal obligation).

${ }^{130}$ Sch. Comm. of Burlington. v. Dep't of Educ. of Mass., 471 U.S. 359, 367 (1985) (The Court granted certiorari to only consider "two issues: whether the potential relief available under $\S 1415(\mathrm{e})(2)$ includes reimbursement to parents for private school tuition and related expenses, and whether $\S 1415(\mathrm{e})(3)$ bars such reimbursement to parents who reject a proposed IEP and place a child in a private school without the consent of local school authorities."). Significantly, the Court also noted that equities were relevant in fashioning relief under the IDEA, a concept that has assumed independent status in many courts' analyses. Id.

${ }^{131} I d$. 


\section{Post-Burlington Analyses}

\section{A. In General}

Following Rowley, the circuit courts proceeded to craft deference standards for IDEA appeals. A majority of the circuit courts have granted district courts the discretion to ignore the conclusions of a hearing officer or SRO. ${ }^{132}$ While some courts have stated that a hearing officer or SRO's factual determinations are presumptively correct, this deference can be vitiated so long as a district court explains why it reached a different result. ${ }^{133}$ A minority approach, elements of which can be detected in the standards of review developed by the Sixth, Seventh, Eighth, and Tenth Circuits, remains faithful to Rowley. ${ }^{134}$ The Sixth Circuit has expressed the doctrine

132 See Lenn v. Portland Sch. Comm., 998 F.2d 1083, 1087 (1st Cir. 1993) (degree of deference is within district court's discretion); M.H. v. N.Y. City Dep't of Educ., 685 F.3d 217, 241-44 (2d Cir. 2012) (district court need only defer to state administrators if it finds their conclusions persuasive); Carlisle Area Sch. v. Scott P. By \& Through Bess P., 62 F.3d 520, 527 (3d Cir. 1995), amended (Oct. 24, 1995); Doyle v. Arlington Cty. Sch. Bd., 953 F.2d 100, 105 (4th Cir. 1991) (district court merely "required to explain" reversal of an administrative officer's factual determinations); Capistrano Unified Sch. Dist. v. Wartenberg, 59 F.3d 884, 891 (9th Cir. 1995) (degree of deference within district court's discretion); Loren F. ex rel. Fisher v. Atlanta Indep. Sch. Sys., 349 F.3d 1309, 1319 (11th Cir. 2003) ("some ... deference" owed to State administrative proceedings; district court may reverse factual findings but "is obliged to explain why"); Reid ex rel. Reid v. D.C., 401 F.3d 516, 522 (D.C. Cir. 2005) (describing district court review as "nondeferential" and less deferential than typical judicial review of agency actions). The Fifth Circuit offers no discernable deference to the administrative proceedings, characterizing its review as "virtually de novo." Klein Indep. Sch. Dist. v. Hovem, 690 F.3d 390, 394 (5th Cir. 2012).

133 See O.S. v. Fairfax Cty. Sch. Bd., 804 F.3d 354, 360 (4th Cir. 2015); Endrew F. ex rel. Joseph F. v. Douglas Cty. Sch. Dist. Re-1, 798 F.3d 1329, 1334 (10th Cir. 2015), cert. granted, No. 15-827, 2016 WL 5416228 (U.S. Sept. 29, 2016); S.H. v. State-Operated Sch. Dist. of City of Newark, 336 F.3d 260, 270 (3d Cir. 2003). The case law uses the Latin term "prima facie," defined by Black's Law Dictionary as: "[a]t first sight; on first appearance but subject to further evidence or information." Prima Facie, Black's Law Dictionary (10th ed. 2014).

134 The Sixth Circuit, as further described below, conducts a deferential review of factual determinations grounded in educational expertise. N.W. ex rel. J.W. v. Boone Cty. Bd. of Educ., 763 F.3d 611, 614 (6th Cir. 2014). The Seventh Circuit 
most cogently: a court must defer to an administrative officer's factual findings that are reasonable and "educational" in nature. ${ }^{135}$

Beyond these generalities, the circuit courts have reached agreement on three discrete propositions. First, each circuit affords some degree of deference for factual findings but none for legal conclusions. ${ }^{136}$ Second, where a hearing officer and SRO disagree, courts agree that deference is owed to the SRO as the final reviewing body. ${ }^{137}$ The notable exception is the Second Circuit, which has

reviews administrative findings of fact under the substantial evidence standard so long as no additional evidence was offered and accepted. M.B. ex rel. Berns v. Hamilton Se. Sch., 668 F.3d 851, 860 (7th Cir. 2011); Alex R., ex rel. Beth R. v. Forrestville Valley Cmty. Unit Sch. Dist. No. 221, 375 F.3d 603, 612 (7th Cir. 2004); Sch. Dist. of Wisconsin Dells v. Z.S. ex rel. Littlegeorge, 295 F.3d 671, 674-75 (7th Cir. 2002). The Eighth Circuit locates its standard of deference, in accordance with Rowley, somewhere between the de novo and substantial evidence tests with particular weight given to hearing officer credibility findings and educational policy determinations. See, e.g., Blackmon ex rel. Blackmon v. Springfield R-XII Sch. Dist., 198 F.3d 648, 654-55 (8th Cir. 1999); Fort Zumwalt Sch. Dist. v. Clynes, 119 F.3d 607, 610 (8th Cir. 1997). The Tenth Circuit presumes that an administrators' findings of fact are correct and has instructed trial courts to "maintain [a deferential] character of review," L.B. ex rel. K.B. v. Nebo Sch. Dist., 379 F.3d 966, 974 (10th Cir. 2004).

${ }^{135}$ N.W. ex rel. J. W., 763 F.3d at $614-15$.

136 O.S., 804 F.3d at 357; C.B. ex rel. B.B. v. Special Sch. Dist. No. 1, Minneapolis, Minn., 636 F.3d 981, 989 (8th Cir. 2011); Draper v. Atlanta Indep. Sch. Sys., 518 F.3d 1275, 1284 (11th Cir. 2008); Reid ex rel. Reid v. D.C., 401 F.3d 516, 521 (D.C. Cir. 2005); Deal v. Hamilton Cty. Bd. of Educ., 392 F.3d 840, 850 (6th Cir. 2004) aff'd sub nom. Deal v. Hamilton Cty. Dep't of Educ., 258 F. App'x 863 (6th Cir. 2008); Amanda J. ex rel. Annette J. v. Clark Cty. Sch. Dist., 267 F.3d 877, 887 (9th Cir. 2001); Warren G. v. Cumberland Cty. Sch. Dist., 190 F.3d 80, 83 (3d Cir. 1999); Muller on Behalf of Muller v. Comm. on Special Educ. of E. Islip Union Free Sch. Dist., 145 F.3d 95 (2d Cir. 1998); O]Toole By \& Through O'Toole v. Olathe Dist. Sch. Unified Sch. Dist. No. 233, 144 F.3d 692, 698 (10th Cir. 1998); Heather S. v. State of Wis., 125 F.3d 1045, 1053 (7th Cir. 1997); G.D. v. Westmoreland Sch. Dist., 930 F.2d 942, 946 (1st Cir. 1991). The Fifth Circuit may be an exception, characterizing its review as "virtually de novo"; it is doubtful that this modicum of deference amounts to deference at all. See Klein Indep. Sch. Dist. v. Hovem, 690 F.3d 390, 394 (5th Cir. 2012).

137 See, e.g., Karl v. Bd. of Educ. of Geneseo Cent. Sch. Dist., 736 F.2d 873, 877 (2d Cir. 1984); Carlisle Area Sch. v. Scott P., 62 F.3d 520, 529 (3d Cir.1995), cert. denied, 517 U.S. 1135 (1996); Thomas v. Cincinnati Bd. of Educ., 918 F.2d 618, 624 (6th Cir. 1990) ("[T]he only logical position, under Rowley and general principles of administrative law, is that federal courts are required to defer to the final decision of the state authorities"); Heather S., 125 F.3d at 1053; Amanda J., 
added a gloss to this otherwise clear rule: district courts may "consider the [hearing officer's] analysis" if an SRO's decision is "insufficiently reasoned to merit ... deference."138 Third, a hearing officer's credibility findings are binding on a reviewing court. ${ }^{139}$ The rationale for this rule is that the hearing officer observed the witnesses and is in the best - and, in many cases ${ }^{140}$ only - position to judge their credibility. ${ }^{141}$ It is worth noting that only a "true" credibility finding will result in deference-so, as the Third Circuit has recognized, if objective evidence in the hearing record contradicts a hearing officer's credibility finding, a reviewing court (or SRO) may disregard it. ${ }^{142}$

The majority and minority approaches are discussed below. The potential for inconsistency under the majority approach is illustrated with two diametrically opposed decisions issued by the Second

267 F.3d at 888; O'Toole, 144 F.3d at 699; but see Guernsey, supra note 43, at 88 (endorsing deference to the SRO only on "educational policy issues," and only if the SRO "has specialized expertise.").

${ }^{138}$ M.H. v. New York City Dep't of Educ., 685 F.3d 217, 246 (2d Cir. 2012).

${ }^{139}$ Carlisle Area Sch. v. Scott P. By \& Through Bess P., 62 F.3d 520, 524 (3d Cir. 1995), amended (Oct. 24, 1995).

${ }^{140}$ While the IDEA requires only that an SRO "conduct an impartial review" and render "an independent decision," its implementing regulations permit at SRO to "[s]eek additional evidence if necessary" and "[a]fford the parties an opportunity for oral or written argument, or both, at the discretion of the reviewing official." 20 U.S.C. $\S 1415$ (g) (2012); 34 C.F.R. $§ 300.514$ (b)(2)(iii), (iv) (2006).

${ }^{141}$ Id. at 529; see also Amanda J., 267 F.3d at 888 (9th Cir. 2001); O'Toole, 144 F.3d at 699; Doyle v. Arlington Cty. Sch. Bd., 953 F.2d 100, 104-05 (4th Cir. 1991); M.W. ex rel. S.W. v. New York City Dep't of Educ., 869 F. Supp. 2d 320, 330 (E.D.N.Y. 2012) aff'd, 725 F.3d 131 (2d Cir. 2013) (citing Carlisle with approval); Fort Osage R-I Sch. Dist. v. Sims ex rel. B.S., No. 09-563-CV-W-F-JG, 2010 WL 3942002, at*11 (W.D. Mo. Sept. 30, 2010) aff'd sub nom. Fort Osage R1 Sch. Dist. v. Sims ex rel. B.S., 641 F.3d 996 (8th Cir. 2011); D.B. ex rel. C.B. v. Houston Indep. Sch. Dist., No. CIV.A. H-06-354, 2007 WL 2947443, at*11 (S.D. Tex. Sept. 29, 2007); R.D. ex rel. Kareem v. D.C., 374 F. Supp. 2d 84, 89 (D.D.C. 2005).

142 Carlisle, 62 F.3d at 529 (SROs "should defer to the hearing officer's findings based on credibility judgments unless the non-testimonial, extrinsic evidence in the record would justify a contrary conclusion or unless the record read in its entirety would compel a contrary conclusion."); accord M.W., 869 F. Supp. 2d at 330 (quoting Carlisle with approval); cf. Doyle, 953 F.2d at 104 (SRO's reversal of hearing officer's credibility determination, without any explanation, was improper). 
Circuit Court of Appeals in 2014. The minority approach is explained by analyzing the Sixth Circuit Court of Appeals' opinion in Burilovich v. Board of Education of the Lincoln Consolidated Schools. ${ }^{143}$

\section{B. The Majority Approach: Infinite Discretion}

In Reyes v. New York City Department of Education, the Second Circuit offered no discernable deference to the SRO, reweighing the evidence in the hearing record to support its preferred outcome. ${ }^{144}$ At the time the Second Circuit issued its decision in Reyes, the student had attended a private school since May 2007. ${ }^{145}$ The student, who was sixteen years old during the disputed school year, exhibited "deficits in cognitive functioning; receptive, expressive, and pragmatic language abilities; and fine and gross motor skills."146 The student had also received diagnoses of "sensory integration dysfunction, moderate mental retardation, and attentiondeficit/hyperactivity disorder."147 The student possessed sensory needs, which, if unmet, caused him to apply pressure to his eyes, rock his body, and knock over objects. ${ }^{148}$

In May 2010, the school district convened an IEP meeting and recommended placement in a special class. ${ }^{149}$ The IEP team also recommended 1:1 paraprofessional services for a period of three months to ease the student's transition into the public school system. ${ }^{150}$ The parents visited the location where the school district intended to implement the IEP and were disappointed to learn that the school did not offer a sensory diet or possess sensory equipment. $^{151}$ The parents also objected to the methodology used

143208 F.3d 560 (6th Cir. 2000).

${ }^{144}$ Reyes ex rel. R.P. v. New York City Dep't of Educ., 760 F.3d 211 (2d Cir. 2014).

${ }^{145} \mathrm{Id}$.

${ }^{146} I d$. at 215.

${ }^{147} \mathrm{Id}$.

${ }^{148} I d$.

${ }^{149} I d$. at 216.

${ }^{150} \mathrm{Id}$.

${ }^{151}$ Reyes ex rel. R.P. v. New York City Dep't of Educ., 760 F.3d 211, 216-17 (2d Cir. 2014). 
within the classroom and determined that the student would not receive an "adequate level of individual attention" in the classroom. ${ }^{152}$ Moreover, the parents predicted that the school could not implement certain services in the May 2010 IEP. ${ }^{153}$ Therefore, the parents rejected the May 2010 IEP and continued the student's enrollment at the private school. ${ }^{154}$

The hearing officer wholly sided with the parents. ${ }^{155}$ With specific respect to the 1:1 paraprofessional, the hearing officer found that the IEP recommended this service for three months only, which precluded the school district from claiming that it would have been offered for the entire school year. ${ }^{156}$ Accordingly, the hearing officer refused to consider this service in its analysis. ${ }^{157}$ An SRO disagreed with the hearing officer, finding that the school district offered the student a FAPE. ${ }^{158}$ Regarding the 1:1 paraprofessional, the SRO found that the student did not require this service to receive a FAPE. ${ }^{159}$ But even assuming that he did, the SRO indicated that the IEP team would be free to reconvene after three months and continue this service. ${ }^{160}$ The district court upheld the SRO, although it opined that the school district could not rely on the possibility that the IEP team could reconvene to defend the IEP's recommendations. ${ }^{161}$

On appeal to the Second Circuit, the court first addressed the amount of deference owed to the administrative proceedings. ${ }^{162}$ After offering an overture to Rowley's "due weight" standard, the court recited an approach borrowed from a post-Burlington II First Circuit case, stating that its degree of deference would "hinge on the

${ }^{152} I d$. at 217.

${ }^{153} \mathrm{Id}$.

${ }^{154} \mathrm{Id}$.

${ }^{155} \mathrm{Id}$.

${ }^{156} \mathrm{Id}$.

${ }^{157}$ Reyes ex rel. R.P. v. New York City Dep't of Educ., 760 F.3d 211, 217 (2d Cir. 2014).

${ }^{158}$ Id. at $217-18$.

${ }^{159} \mathrm{Id}$.

${ }^{160} \mathrm{Id}$.

${ }^{161} I d$. at 218.

${ }^{162} I d$. 
kinds of considerations that normally determine whether any particular judgment is persuasive."163

Turning first to the 1:1 paraprofessional dispute, the court endorsed the district court's conclusion that the school district was bound by the three-month time period and could not rely upon the possibility of continuing these services. ${ }^{164}$ With respect to the SRO's conclusion that the student did not require these services to receive a FAPE, the court independently considered the evidence that was before the SRO and reached an opposite conclusion. ${ }^{165}$ The court did not deem the SRO's conclusions unfounded or unsupported by the record; it simply combated these conclusions with other evidence. ${ }^{166}$ For example, the SRO noted that a November 2009 classroom observation of the student at the private school described the student's abilities to, among other things, "answer questions . . . ask a peer a question, [and] accept redirection and prompts related to activities."167 This evidence supported a conclusion that the student did not need a 1:1 paraprofessional to receive a FAPE. ${ }^{168}$ The Second Circuit, however, discounted it by observing that "these interactions took place in a classroom containing at first five students and three adults, and later seven students and five adults." 169 Having found the SRO's conclusions unpersuasive, the Reyes court reversed the district court and found in favor of the parents. ${ }^{170}$ As for the remaining claims pertaining to the methodology used at the assigned

${ }^{163}$ Reyes ex rel. R.P. v. New York City Dep’t of Educ., 760 F.3d 211, 218 (2d Cir. 2014). The Second Circuit quoted M.H. v. New York City Department of Education, 685 F.3d 217, 244 (2d Cir. 2012), which, in turn, quoted Lenn $v$. Portland School Committee, 998 F.2d 1083, 1086-87 (1st Cir. 1993). Judge Bruce Selya, known for his colorful vocabulary and ebullient writing personality, authored Lenn. See David Franklin, Judge Bruce Selya, Resipiscent Recidivist, 1 GREEN BAG 2d 95 (1997).

${ }^{164}$ Reyes, 760 F.3d at $221-22$.

${ }^{165} \mathrm{Id}$.

166 See id.

${ }^{167}$ Id.

${ }^{168} \mathrm{Id}$.

${ }^{169}$ Reyes ex rel. R.P. v. New York City Dep't of Educ., 760 F.3d 211, 222 (2d Cir. 2014).

${ }^{170} \mathrm{Id}$. 
public school site and its lack of sensory supports, the court demurred, stating that it "need not . . . address th[o]se issues." 171

Hardison v. Board of Education of the Oneonta City School District, issued less than five months after Reyes, provides a striking contrast. ${ }^{172}$ Hardison involved a request for tuition reimbursement, the remedy approved of by the Supreme Court in its appeal of Burlington II. ${ }^{173}$ This remedy is available to parents who, dissatisfied with the recommendations of an IEP, unilaterally enroll their child in a private school. ${ }^{174}$ If a parent files a due process complaint notice and an administrative officer finds that (1) the school district did not offer the student a FAPE; and (2) the private school was appropriate to meet the student's needs, the school district must reimburse the parent for tuition paid to the private school during the disputed school year. ${ }^{175}$ In determining whether a private placement is appropriate, courts and administrators generally ask whether it offered specially designed instruction to meet a student's unique needs. ${ }^{176}$

The facts of Hardison elicit empathy. The student experienced a precipitous personal and academic decline in 2006, her ninth grade year. ${ }^{177}$ While the student had a history of depression and "oppositional issues," these issues became more pronounced during the fall of 2006. ${ }^{178}$ The student completed the 2006-07 school year

${ }^{171} I d$.

${ }^{172}$ Hardison v. Bd. of Educ. of the Oneonta City Sch. Dist., 773 F.3d 372, 386-89 (2d Cir. 2014). Further reflective of the discretionary review standard, two Judges who served on the Reyes panel served on the Hardison panel.

173 The remedy was later codified into the language of the IDEA, 20 U.S.C. $\S$ 1412(a)(10)(C)(ii) (2012); see also Florence Cty. Sch. Dist. Four v. Carter By \& Through Carter, 510 U.S. 7 (1993); Sch. Comm. of Town of Burlington, Mass. v. Dep't of Educ. of Mass., 471 U.S. 359, 373-74 (1985).

17420 U.S.C. $\$ 1412$ (a)(10)(C)(ii) (2012).

175 Additionally, as recognized by the Court in Burlington, "equitable considerations are relevant in fashioning relief," Burlington, 471 U.S. 359, 374 (1985). Many courts conceive of equitable considerations as a third requirement that must be assessed before tuition may be awarded to a parent.

176 See generally Perry A. Zirkel, Tuition and Related Reimbursement Under the Idea: A Decisional Checklist, 282 ED. LAW REP. 785, 791-92 (2012).

${ }^{177}$ Hardison v. Bd. of Educ. of the Oneonta City Sch. Dist., 773 F.3d 372, 377 (2d Cir. 2014).

${ }^{178}$ Id. 
having received twenty-five disciplinary reports and failing grades in "all but two" of her classes. ${ }^{179}$ The student returned to the public high school to repeat ninth grade during the 2007-08 school year. ${ }^{180}$ But less than a month after the school year began, she ran away and attempted suicide. ${ }^{181}$ The student continued to struggle with mental health issues during the 2007-08 school year. ${ }^{182}$

The parents e-mailed the school district in March 2008, stating that the student was "collapsing into depression."183 The parents further indicated that they were considering placing the student in "a hospital or other therapeutic environment."184 The parents eventually informed the school district that they would enroll the student at the Family Foundation School, a "therapeutic boarding school." 185 The school district submitted the student's transcript to Family Foundation and the student enrolled at Family Foundation. ${ }^{186}$ With the exception of a few weeks, the student remained at Family Foundation for the duration of the disputed school years. ${ }^{187}$ The parents filed a due process complaint notice in February 2009 seeking tuition reimbursement for the 2008-09 and 2009-10 school years. ${ }^{188}$

A hearing officer found that the school district denied the student a FAPE and that Family Foundation was appropriate for the student. ${ }^{189}$ An SRO reversed, finding that there was insufficient evidence in the record as to how Family Foundation addressed the student's needs. ${ }^{190}$ Of particular relevance to the SRO was the "dearth of testimony as to [the student's] academic and therapeutic

${ }^{179} \mathrm{Id}$.

${ }^{180} I d$. at $377-78$.

${ }^{181} \mathrm{Id}$. at 378 .

${ }^{182} \mathrm{Id}$.

${ }^{183}$ Hardison v. Bd. of Educ. of the Oneonta City Sch. Dist., 773 F.3d 372, 379, 384 (2d Cir. 2014).

${ }^{184} \mathrm{Id}$. at 379.

${ }^{185} \mathrm{Id}$.

${ }^{186} \mathrm{Id}$.

${ }^{187}$ See generally id. at 379-83.

${ }^{188} \mathrm{Id}$. at 381.

${ }^{189}$ Hardison v. Bd. of Educ. of the Oneonta City Sch. Dist., 773 F.3d 372, 384 (2d Cir. 2014).

${ }^{190}$ Id. at $384-85$. 
progress . . . from those who were directly providing educational and one-on-one counseling services." 191 The district court, which did not accept additional evidence, reversed the SRO. ${ }^{192}$ The court discarded SRO findings pertaining to, among other things, the nature of Family Foundation, the weight afforded to evidence regarding the student's progress, and the nature of counseling services identified on the student's IEPs. ${ }^{193}$

On appeal, the Second Circuit reinstated the entirety of the SRO's analysis. ${ }^{194}$ The court began by noting that the SRO and district court considered the same evidence but reached different conclusions. ${ }^{195}$ Notwithstanding this disagreement, because the SRO's decision was "sufficiently reasoned and supported by the record," the court held that the district court had no authority to reverse it. ${ }^{196}$ The court afforded deference to the SRO's substantive conclusions as well as his finding that the hearing record did not contain enough evidence to make a determination regarding the appropriateness of Family Foundation. ${ }^{197}$

The court offered a ringing endorsement of the educational expertise rationale expressed in Rowley:

The determination made by the SRO . . . is a function of the specialized knowledge and expertise possessed in greater degree by state educational policy-makers than by the courts. That we or the district court may otherwise be willing to draw conclusions from pieces of evidence that the SRO did not believe were appropriate is not enough to demonstrate insufficient reasoning on the part of the SRO. ${ }^{198}$

The court continued:

${ }^{191} I d$.

${ }^{192} I d$. at 385.

${ }^{193} I d$.

${ }^{194} I d$.

195 Hardison v. Bd. of Educ. of the Oneonta City Sch. Dist., 773 F.3d 372, 386 (2d Cir. 2014).

${ }^{196} I d$.

${ }^{197}$ Id. at 387.

${ }^{198}$ Id. 
It is precisely because we recognize that state educational authorities possess greater expertise in drawing conclusions from educational proceedings that it is clearly established in this Circuit that "deference to 'administrative proceedings is particularly warranted where,' " as here, " 'the district court's decision was based solely on the administrative record.' " 199

Yet, despite this, the court proceeded to conduct an "independent" analysis of the evidence in the hearing record regarding Family Foundation. $^{200}$ It is unclear whether the court felt this analysis was required, or whether it was being overly cautious. In any event, it speaks to the uncertainty of the discretionary standard of review applied by most circuit courts.

\section{The Minority Approach: Deference for Educational Findings}

Burilovich v. Board of Education of the Lincoln Consolidated Schools is a representative example of Sixth Circuit case law, which, in turn, embodies the minority approach to deference. ${ }^{201}$ In Burilovich, parents challenged an IEP that did not prescribe discrete trial training (DTT), a methodology favored by the parents. ${ }^{202}$ At the age of three, the student began receiving special education services. ${ }^{203}$ An evaluation from February 1994 resulted in a diagnosis

199 Id. (quoting M.H. v. N.Y.C Dep't of Educ., 685 F.3d 217, 244 (2d Cir. 2012) which, in turn, quoted A.C. v. Bd. of Educ. of the Chappaqua Cent. Sch. Dist., 553 F.3d 165, 171 (2d Cir. 2009)).

${ }^{200}$ Hardison, 773 F.3d at 387-88.

${ }^{201}$ Burilovich v. Bd. of Educ. of Lincoln Consol. Sch., 208 F.3d 560, 562 (6th Cir. 2000). For other Sixth Circuit cases, see Thomas v. Cincinnati Bd. of Educ., 918 F.2d 618, 624 (6th Cir. 1990); Roncker On Behalf of Roncker v. Walter, 700 F.2d 1058, 1061-62 (6th Cir. 1983); McLaughlin v. Holt Pub. Sch. Bd. of Educ., 320 F.3d 663, 669 (6th Cir. 2003); Deal v. Hamilton Cty. Bd. of Educ., 392 F.3d 840, 850 (6th Cir. 2004) aff'd sub nom. Deal v. Hamilton Cty. Dep't of Educ., 258 F. App'x 863 (6th Cir. 2008). The Second Circuit originally endorsed this approach, but gradually converted to the majority view, see Adler by Adler v. Educ. Dep]t of State of N.Y., 760 F.2d 454, 458 (2d Cir. 1985).

${ }^{202}$ See Burilovich, 208 F.3d at 564.

${ }^{203} \mathrm{Id}$. at 563. 
of autism. ${ }^{204}$ Following this diagnosis, the parents researched educational approaches for children with autism and came across DTT. ${ }^{205}$ The parents subsequently initiated a home-based program utilizing DTT. ${ }^{206}$ From that time forward, the student received services within a school program as well as home-based DTT services. ${ }^{207}$

At an IEP team meeting in October 1994, the parents requested, without success, that the school district utilize DTT during the school day. ${ }^{208}$ The student's teacher, however, agreed to provide 30 minutes of DTT prior to school on the days that the student attended school. $^{209}$ The school district hired a new director of special education in September 1995, and this director worked with the parents during the ensuing months. ${ }^{210}$

In March 1996, an IEP team recommended a program consisting "predominantly" of DTT. ${ }^{211}$ The school district's director of special education later testified that this was done "to avoid conflict and a due process hearing." 212 After the meeting, the director received backlash from school staff who felt that DTT was ill-suited for the student. ${ }^{213}$ The school district convened a second IEP team meeting in May 1996. ${ }^{214}$ In an about-face, the director explained to the parents that the school district was reversing course and would not offer DTT to the student. ${ }^{215}$ The parents, understandably miffed, filed a due process complaint notice. ${ }^{216}$

${ }^{204} \mathrm{Id}$.

${ }^{205} \mathrm{Id}$.

${ }^{206} \mathrm{Id}$.

${ }^{207}$ Burilovich v. Bd. of Educ. of Lincoln Consol. Sch., 208 F.3d 560, 563 (6th Cir. 2000).

${ }^{208} \mathrm{Id}$.

${ }^{209} \mathrm{Id}$.

${ }^{210} \mathrm{Id}$. at $563-64$.

${ }^{211} I d$. at 564.

${ }^{212} \mathrm{Id}$.

${ }^{213}$ Burilovich v. Bd. of Educ. of Lincoln Consol. Sch., 208 F.3d 560, 564 (6th Cir. 2000).

${ }^{214} \mathrm{Id}$.

${ }^{215} \mathrm{Id}$.

${ }^{216} I d$. 
A hearing officer found that the March 1996 IEP team meeting's proposal constituted an IEP that the school district was obligated to implement. $^{217}$ An SRO reversed, finding that the March 1996 discussion was preliminary in nature, and that the May 1996 IEP offered the student a FAPE. ${ }^{218}$ The district court agreed with the SRO. ${ }^{219}$ The parents appealed to the Sixth Circuit, which, before addressing the parties' claims, considered the standard of review of an IDEA state administrative proceeding in federal court.

The court began its analysis by citing Rowley's two-part test and accurately reciting its distinction between procedure and substance. ${ }^{20}$ The court stated that procedural claims were to be "strictly review[ed]" by courts while substantive conclusions should receive deference. ${ }^{221}$ In explaining this distinction, the court reiterated Rowley's federalism concerns and spoke to the judiciary's relative competence: "courts are generalists with no expertise in the educational needs of handicapped children and will benefit from the factfinding of a state agency, which is presumed to have expertise in the field." 222

Beyond procedure and substance, the court also drew a distinction between educational and non-educational factual findings. The court reasoned that " $[\mathrm{t}]$ he focus of the [Rowley] Court ... upon the presumed educational expertise of state and local agencies leads to the conclusion that the amount of weight due depends upon whether such expertise is relevant to the decision-making process." 223 Thus, if a finding is educational in nature, it is owed deference. In not, a court need not defer to it because "a federal court would be just as well suited to evaluate the situation." 224

The court next articulated how much weight should be afforded to educational findings. As did Rowley, the court located the

${ }^{217} I d$.

${ }^{218} I d$.

${ }^{219}$ Burilovich v. Bd. of Educ. of Lincoln Consol. Sch., 208 F.3d 560, 564 (6th Cir. 2000).

${ }^{220} \mathrm{Id}$. at $565-67$.

${ }^{221} \mathrm{Id}$. at 566.

${ }^{222} I d$.

${ }^{223} \mathrm{Id}$. at 567.

${ }^{224}$ Burilovich v. Bd. of Educ. of Lincoln Consol. Sch., 208 F.3d 560, 567 (6th Cir. 2000). 
standard somewhere between the substantial evidence and the de novo standards. ${ }^{225}$ The court settled on the following formulation: "[a] court should defer to the administrative findings only when educational expertise is relevant to those findings and the decision is reasonable." 226 The rule is clear and simple. And, as discussed further below, it slyly incorporates the substantial evidence test.

Turning to the merits of the case, the Sixth Circuit upheld the district court, which, in turn, had upheld the SRO. ${ }^{227}$ The court reviewed the parents' contentions, affording due weight to the SRO's conclusions as to whether the May 1996 IEP addressed the student's needs, and whether this IEP would allow the student to attain his maximum potential. ${ }^{228}$

The court first considered five procedural challenges presented by the parents and resolved each of these in favor of the school district. $^{229}$ Next, the court turned to the parents' two substantive claims. $^{230}$ Preliminarily, the court afforded "due weight" to the SRO's conclusion that the IEP addressed the student's unique needs. ${ }^{231}$ The court rejected the parents' argument that the district court impermissibly resolved a disputed and material fact; a review of the record showed that the district court had merely affirmed the SRO's factual findings. ${ }^{232}$ Next, the court considered whether the May 1996 IEP was designed to allow the student to reach his maximum potential. ${ }^{233}$ The court acknowledged the "widely differing views" of the parents and the school district and noted that the record contained divergent testimony as to what did, or would, work best for the student. ${ }^{234}$ Recognizing that the SRO and district

${ }^{225} \mathrm{Id}$.

${ }^{226} \mathrm{Id}$.

${ }^{227} \mathrm{Id}$. at 572 .

${ }^{228} \mathrm{Id}$. at $567-72$.

${ }^{229} \mathrm{Id}$. at $567-70$.

${ }^{230}$ Burilovich v. Bd. of Educ. of Lincoln Consol. Sch., 208 F.3d 560, 570-72

(6th Cir. 2000).

${ }^{231} \mathrm{Id}$. at 571 .

${ }^{232} \mathrm{Id}$.

233 See id. at 570-72. The court applied a "maximum potential" standard instead of the FAPE standard based on a requirement imposed by State law (Michigan). Id. at 565.

${ }^{234}$ Id. at 571. 
court resolved the issue in favor of the district, and that the record provided "reasonable bases" for these views, the court deferred to the SRO's determination. ${ }^{235}$

While Burlington II read Rowley as narrowly as possible, Burilovich grappled with its reasoning. In doing so, the Burilovich Court articulated a standard of review that synthesized the concerns and requirements of Rowley.

\section{Procedure Versus Substance: A Reasoned Approach to DEFERENCE}

Twenty years after its creation, the majority of circuits have effectively abandoned the Rowley deference standard, even though Rowley remains the sole and authoritative message from the Supreme Court on this issue. In this section, drawing guidance from Rowley and the minority approach, I propose an approach to deference that is in keeping with both Rowley and the structure of the IDEA.

At the outset, the discretionary deference standard adopted by the majority of circuit courts must be rejected. For one, it contradicts the language of Rowley, giving no heed to its admonition that courts should avoid imposing their educational views on States. Additionally, there are strong social policies that militate in favor of deference. The three factors identified above pertaining to administrative deference-expertise, legislative delegation, and political accountability-certainly apply. ${ }^{236}$ The expertise rationale is particularly compelling. Federal judges, their good intent notwithstanding, are not well-equipped to make special education programming decisions. ${ }^{237}$ As Professor Perry A. Zirkel has explained:

[W]hy would a judge have more knowledge to decide the case than the hearing officer, who directly viewed the witnesses and has developed specialized education expertise? Such expertise is generally inversely proportional to the level of dispute resolution, with the state or federal highest court being the least likely to

${ }^{235} \mathrm{Id}$. at 572.

${ }^{236}$ See supra notes $61-65$.

${ }^{237}$ Burilovich v. Bd. of Educ. of Lincoln Consol. Sch., 208 F.3d 560, 567 (6th Cir. 2000). 
understand the realities of the student's special education status and services. ${ }^{238}$

Three additional policy considerations apply specifically to judicial review of IDEA proceedings. The first is efficiency. As the Court of Appeals for the District of Columbia put it, non-deferential judicial review of administrative proceedings imposes "costs ... on [both] parties [by] having still another person redecide the matter from scratch." 239 The second is federalism. Education is chiefly reserved to the several states, and a federal court impinges upon a state's authority by dictating its educational policy. Moreover, states have a better understanding of the nuances of their educational systems. ${ }^{240}$ The third is the minimization of uncertainty. Having litigated a matter through one or two levels of administrative hearings, victorious parties may nevertheless have to present their case anew in court. And, the outcome of these efforts is largely dependent upon how much effort a judge is willing or disposed to invest in the appeal. Affording the state proceedings deference allows parties to better assess the feasibility of an appeal, which, in turn, discourages unnecessarily prolonged litigation. ${ }^{241}$

Having rejected the discretionary standard of review, it is necessary to determine the precise contours of "due weight." As noted above, the two key questions are what and how much: what kind of determinations receive due weight, and how much deference

${ }^{238}$ Perry A. Zirkel, The Over-Legalization of Special Education, 195 ED. LAw REP. 35, 37 (2005). Professor Zirkel noted that this may not apply if a case presents a novel legal issue. See id. Professor Zirkel has elsewhere recommended amendment of the IDEA to restrict the availability and scope of judicial review, including "specify[ing] a traditional substantial evidence standard of review and limit[ing] the taking of additional evidence to exceptional cases," Zirkel, Over-Due Process Revisions, supra note 8, at 410; see also United States v. Mead Corp., 533 U.S. 218, 250 (2001) (Scalia, J.J., dissenting) ("when the ambiguities (intended or unintended) that [federal] statutes contain are innumerable, totality-of-thecircumstances [discretionary] deference is a recipe for uncertainty, unpredictability, and endless litigation.”).

${ }^{239}$ Kerkam v. McKenzie, 862 F.2d 884, 887 (D.C. Cir. 1988).

${ }^{240}$ Zirkel, supra note 238, at 37.

${ }^{241}$ See Zirkel, supra note 8, at 410 ("restrict[ing] the option of judicial review ... would have obvious advantages in terms of saving time and other transaction costs, thus redirecting attention and resources to the education of students with disabilities."). 
do these determinations receive? Turning first to the question of what, the venerable fact/law distinction is a helpful starting point. ${ }^{242}$ The circuit courts agree that courts owe agencies no deference for statements of law. ${ }^{243}$ This leaves findings of fact.

As both Rowley and the minority approach recognize, findings of fact encompass a range of issues, some of which are within the agency's expertise and some of which are not. Rowley drew a distinction between procedure and substance, while the minority approach, discussed above, distinguished educational from noneducational findings. I contend that both tests attempt to draw the

242 Professor Thomas F. Guernsey implicitly recognized the problem of separating administrative decisions into law and fact in discerning four different kinds of factual and/or legal findings: (1) purely historical fact decisions; (2) "strictly" policy questions; (3) factual questions concerning the appropriateness of a program for a particular child; and (4) legal questions concerning the interpretation of the statute. Guernsey, supra note 43, at 80-81. Professor Guernsey suggested that each category should possess its own standard of review. Id.

${ }^{243}$ While beyond the scope of this article, this question - whether a federal court owes deference to a state agency's legal interpretation of the IDEAdeserves more attention than it is given. Strictly speaking, the deferential Chevron rule governing review of federal agency adjudications does not apply because Congress merely indicated that States must operate due process hearing systems as a precondition for receiving IDEA funds. 20 U.S.C. § 1412(a), (a)(6)(A); 20 U.S.C. § 1415(f), (i) (2012); see generally United States v. Mead Corp., 533 U.S. 218, 226-27 (2001); Christensen v. Harris County, 529 U.S. 526 (2001); Chevron, U.S.A., Inc. v. Natural Res. Def. Council, Inc., 464 U.S. 837, 851 (1984). However, practically speaking, state administrators possess specialized expertise in IDEA adjudication, which is an oft-repeated rationale for deference. See Lipton, supra note 62, at 2121; see also 34 C.F.R. § 300.511(c) (2006) (identifying minimum qualifications for hearing officers, including "knowledge of ... the [IDEA], Federal[,] and State regulations pertaining to the [IDEA], and legal interpretations of the [IDEA] by federal and state courts" as well as the ability to conduct hearings and write decisions "in accordance with appropriate, standard legal practice."). Nevertheless, federal courts have declined to defer to state administrators' legal interpretations. Professor Weiser has described a similar response by federal courts to state legal interpretations under the Telecommunications Act of 1996. See Weiser, Federal Common Law, supra note 27, at 1739 ("Federal courts remain somewhat uncomfortable with allowing states to exercise discretion on the meaning of federal law and thus almost uniformly reject the argument that reasonable state agency interpretations of the [Telecommunications] Act merit judicial deference."). 
same distinction. ${ }^{244}$ The Rowley Court's emphasis on procedure implied that courts should take an active role in policing the IDEA's procedural requirements. After all, according to the Court, the IDEA's procedural requirements (i.e., non-educational issues) are "highly specific," which makes them amenable to judicial review. ${ }^{245}$ Substantive requirements, by contrast, ask whether educational services were reasonably calculated to-or, in fact, did-provide educational benefit. ${ }^{246}$ These determinations involve educational policy choices which, as Rowley recognized, are better left to state administrators. ${ }^{247}$

Distinguishing procedure from substantive is not always easy or straightforward. Indeed, posed with this difficulty, several circuit courts have identified substantive issues as mixed questions of law and fact and reviewed state administrative findings de novo. ${ }^{248}$ But this is where the Sixth Circuit's insights provide guidance-for example, in determining whether a challenge to an IEP's annual

${ }^{244}$ For simplicity's sake, I use "procedure" and "substance" throughout the remainder of the article.

${ }^{245}$ Rowley v. Bd. of Ed. Of Hendrick Hudson Cent. Sc. Dist., 458 U.S. 176, 205 (1982); see also Jose P. v. Ambach, 557 F. Supp. 1230, 1243 (E.D.N.Y. 1983) ("it is clear, and the Rowley case illustrates, that 'quality' or 'programmatic' issues are less yielding to judicial determination.").

246 This test would similarly apply when assessing whether a parent's unilateral placement is appropriate under the Act. See supra notes 171-75 and accompanying text.

${ }^{247}$ This test would also apply to judicial review of the IDEA's manifestation determination review (MDR) procedure. This portion of the IDEA pertains to the procedure by which a school district may impose discipline upon a student with a disability lasting more than 10 school days. See 20 U.S.C. $\S 1415(\mathrm{k})$ (2012); 34 C.F.R. $\S \S 300.530-300.537$ (2006). Procedural issues would include, for instance, whether or not an MDR meeting was convened and whether the required members attended. Substantive issues would include whether "the conduct in question was caused by, or had a direct and substantial relationship to, the child's disability;" and "if the conduct in question was the direct result of the [school district's] failure to implement the IEP." See 20 U.S.C. § 1415 (k)(1)(E)(i) (2012).

248 Bd. of Educ. of Fayette Cty., Ky. v. L.M., 478 F.3d 307, 313 (6th Cir. 2007); K.E. ex rel. K.E. v. Indep. Sch. Dist. No. 15, 647 F.3d 795, 804 (8th Cir. 2011); Gregory K. v. Longview Sch. Dist., 811 F.2d 1307, 1310 (9th Cir. 1987); Loren F. ex rel. Fisher v. Atlanta Indep. Sch. Sys., 349 F.3d 1309, 1313 (11th Cir. 2003). Application of the mixed question concept to substantive IDEA claims is a particularly poor fit as it, paradoxically, results in hearing officers and SROs receiving the least amount of deference in their greatest area of expertise. 
goals is procedural or substantive, a court would look at a hearing officer or SRO's findings and ask if they required educational expertise. If the issue is whether an IEP's annual goals contained (or were required to contain) short-term objectives, the answer would be no. But if the question was whether the student could be reasonably expected to achieve an IEP's annual goals within a year, this is substantive in nature and deference would be required.

The second question remains: how much deference does due weight require? For procedural findings, I contend that a court may engage in de novo review or, in other words, dispense with any deference. $^{249}$ The reason for this is, as the Second Circuit has stated, a "district court [i]s as well-positioned as ... state administrative officials" to interpret the IDEA. ${ }^{250}$ For substantive findings, I propose a test in accord with the Sixth Circuit's: courts must defer to the reasonable conclusions of state administrative officials. ${ }^{251}$ This means that if a hearing officer or SRO's conclusion is supported by evidence in the hearing record, a court must adopt this conclusion even if it would weigh the evidence differently. ${ }^{252}$

This is, in essence, the "substantial evidence" test. At first blush, this would appear to contradict Rowley, but as discussed above, Rowley contains an extensive discussion of which IDEA claims fall within the province of the judiciary and which primarily rest with

249 See generally Berry, supra note 30 (arguing that courts should conduct de novo review of federal agencies" interpretation of "procedural provisions" contained within agencies' enabling statutes).

${ }^{250}$ Muller ex rel. Muller v. Comm. on Special Educ. of E. Islip Union Free Sch. Dist., 145 F.3d 95, 102 (2d Cir. 1998), accord McLaughlin v. Holt Pub. Sch. Bd. of Educ., 320 F.3d 663, 669 (6th Cir. 2003) ("Less weight is due to an agency's determinations on matters for which educational expertise is not relevant because a federal court is just as well suited to evaluate the situation.").

${ }^{251}$ Professor David Zaring has argued that, no matter what standard of review a court ostensibly applies, courts do (and should) apply a simple reasonableness test, asking if an administrative agency's challenged action was reasonable. Zaring, supra note 63, at 192. Professor Zaring quotes Judge Richard Posner, who wrote that " $[\mathrm{t}]$ he only distinction the judicial intellect actually makes is between deferential and nondeferential review." $I d$.

252 Additionally, as noted in the Second Circuit's decision in Hardison, educational expertise may be relevant to a determination that the evidence in the hearing record is insufficient to make a determination on a substantive issue. Hardison v. Bd. of Educ. of the Oneonta City Sch. Dist., 773 F.3d 372, 387 (2d Cir. 2014). 
state administrative officials. As the Seventh Circuit has recognized, Rowley's holding cannot be untethered from this discussion. ${ }^{253}$ In M.B. ex rel. Berns v. Hamilton Southeastern Schools, the Seventh Circuit recited its obligation to "give due weight to the factual determinations of the administrative tribunals." 254 The court defined due weight to mean "the usual deference that reviewing courts owe agencies when judicial review is limited to the administrative record," explicitly defining this as "a clear-error" or "substantialevidence" standard. ${ }^{255}$ While this appears an abnegation of Rowley, it is, in fact, faithful to its teachings.

Moreover, labels aside, Rowley suggested that courts should generally refrain from opining as to the substance of IEPs. As Rowley stated, "adequate compliance with the procedures prescribed would in most cases assure much if not all of what Congress wished in the way of substantive content in an IEP." 256 A deferential standard of review, then, properly returns the focus to the IDEA's procedures and affords administrative officers the discretion to determine whether educational services were appropriate to meet the needs of students with disabilities.

\section{CONCLUSION}

The IDEA's multilayered administrative and judicial review procedure is predisposed toward confusion. This article seeks to clarify an unresolved but important question: how much deference federal courts owe to state administrative proceedings. Rowley and public policy considerations instruct that federal courts must defer to administrators' substantive or educational findings, but should review procedural or non-educational findings, as well as legal conclusions,

253 Alex R., ex rel. Beth R. v. Forrestville Valley Cmty. Unit Sch. Dist. No. 221, 375 F.3d 603, 612 (7th Cir. 2004); M.B. ex rel. Berns v. Hamilton Se. Sch., 668 F.3d 851, 860 (7th Cir. 2011). The Sixth Circuit also grasps this distinction but facially maintains that its standard of review falls short of the substantial evidence test. See Burilovich v. Bd. of Educ. of Lincoln Consol. Sch., 208 F.3d 560, 567 (6th Cir. 2000).

${ }^{254} 668$ F.3d 851, 860 (7th Cir. 2011) (internal quotations omitted).

${ }^{255} \mathrm{Id}$. (internal quotations omitted).

${ }^{256}$ Rowley v. Bd. of Ed. Of Hendrick Hudson Cent. Sc. Dist., 458 U.S. 176, 206 (1982). 
de novo. This approach allocates an important aspect of decisionmaking power to the States, who bear the "primary responsibility" of IDEA compliance. ${ }^{257}$

Moreover, allowing federal judges plenary review over state administrative proceedings aligns with a system of review the Supreme Court has criticized as "ponderous."258 Restricting the extent to which courts may review substantive or educational findings shifts the goal toward efficiency. This, in turn, promotes resolution of disputes at the state level, providing a cheaper and quicker (i.e., non-ponderous) solution to parties' disagreements. And more importantly, it returns the parties to a goal that can be too easily forgotten during adversarial proceedings: the education of a student with a disability.

${ }^{257}$ Bd. of Educ. of Hendrick Hudson Cent. Sch. Dist., Westchester Cty. v. Rowley, 458 U.S. 176, 183 (1982); see also id. at 207-08 ("In the face of such a clear statutory directive, it seems highly unlikely that Congress intended courts to overturn a State's choice of appropriate educational theories in a [due process] proceeding ...").

${ }^{258}$ Honig v. Doe, 484 U.S. 305, 322 (1988); Burlington School Comm. v. Mass. Dept. of Educ., 471 U.S. 359, 370 (1985). 